\title{
COVID-19 and Neurological Impairment: Hypothalamic Circuits and Beyond
}

\author{
Bashair M. Mussa $^{1, *(\mathbb{D})}$, Ankita Srivastava ${ }^{2}(\mathbb{D})$ and Anthony J. M. Verberne $^{3}(\mathbb{D})$ \\ 1 Basic Medical Science Department, College of Medicine, University of Sharjah, \\ Sharjah 27272, United Arab Emirates \\ 2 Sharjah Institute for Medical Research and College of Medicine, University of Sharjah, \\ Sharjah 27272, United Arab Emirates; ankita2112@gmail.com \\ 3 Department of Medicine, Austin Health, University of Melbourne, Heidelberg 3084, Australia; \\ antonius@unimelb.edu.au \\ * Correspondence: bmussa@sharjah.ac.ae; Tel.: +971-65057220
}

Citation: Mussa, B.M.; Srivastava, A.; Verberne, A.J.M. COVID-19 and Neurological Impairment: Hypothalamic Circuits and Beyond. Viruses 2021, 13, 498. https:// doi.org/10.3390/v13030498

Academic Editor: Stefano Aquaro

Received: 10 January 2021

Accepted: 26 February 2021

Published: 17 March 2021

Publisher's Note: MDPI stays neutral with regard to jurisdictional claims in published maps and institutional affiliations.

Copyright: (C) 2021 by the authors Licensee MDPI, Basel, Switzerland. This article is an open access article distributed under the terms and conditions of the Creative Commons Attribution (CC BY) license (https:// creativecommons.org/licenses/by/ $4.0 /)$.

\begin{abstract}
In December 2019, a novel coronavirus known as severe acute respiratory syndrome coronavirus 2 (SARS-CoV-2) emerged in Wuhan, the capital of Hubei, China. The virus infection, coronavirus disease 2019 (COVID-19), represents a global concern, as almost all countries around the world are affected. Clinical reports have confirmed several neurological manifestations in COVID19 patients such as headaches, vomiting, and nausea, indicating the involvement of the central nervous system (CNS) and peripheral nervous system (PNS). Neuroinvasion of coronaviruses is not a new phenomenon, as it has been demonstrated by previous autopsies of severe acute respiratory syndrome coronavirus (SARS-CoV) patients who experienced similar neurologic symptoms. The hypothalamus is a complex structure that is composed of many nuclei and diverse neuronal cell groups. It is characterized by intricate intrahypothalamic circuits that orchestrate a finely tuned communication within the CNS and with the PNS. Hypothalamic circuits are critical for maintaining homeostatic challenges including immune responses to viral infections. The present article reviews the possible routes and mechanisms of neuroinvasion of SARS-CoV-2, with a specific focus on the role of the hypothalamic circuits in mediating the neurological symptoms noted during COVID19 infection.
\end{abstract}

Keywords: COVID-19; SARS-CoV-2; neurological manifestations; hypothalamic circuits; olfactory bulb; respiratory centers; hypothalamic-pituitary-adrenocortical axis; viral infection

\section{Introduction}

In the third week of December 2019, a novel coronavirus, now known as severe acute respiratory syndrome coronavirus 2 (SARS-CoV-2), emerged in Wuhan, the capital of Hubei province, China [1]. This virus causes a serious respiratory illness including lung failure and pneumonia that has been officially named COVID-19 by the World Health Organization [2]. SARS-CoV-2 shares a highly homologous sequence with severe acute respiratory syndrome coronavirus (SARS-CoV); hence, its clinical symptoms are similar to those reported for SARS-CoV [3]. The pandemic represents a global health concern, as almost all countries around the world are affected, and more than 79 million confirmed cases were reported by the end of December 2020 [2]. The common clinical features of COVID-19 infection are fever, cough, fatigue, sputum production, headache, hemoptysis, diarrhea, dyspnea, and lymphopenia [4,5]. In addition, patients with this infection exhibit symptoms associated with induced systemic and localized immune responses and increased levels of inflammation [6]. More importantly, a considerable number of affected patients, about $34 \%$, develop neurological symptoms, categorized into central nervous system (CNS) and peripheral nervous system (PNS) symptoms [7]. The clinical features that are related to the former include headache, dizziness, disturbance of consciousness, 
acute cerebrovascular disease, and epilepsy, whereas symptoms such as decreased taste, decreased smell, and appetite were associated with the latter [7].

The alarming continuous increase in the number of patients who exhibit neurological manifestations reflects a significant neurological impairment and negative impact on the CNS. Therefore, it is critical to understand the central mechanisms associated with COVID-19 infection and to identify the regions within the CNS that may be involved in the neurological pathogenesis of COVID-19 [8]. Based on the array of neurological symptoms, we believe that hypothalamic circuits are key players in the development of the symptoms that are related to the CNS and PNS manifestations of COVID-19. The hypothalamic circuits receive a great deal of input from the olfactory system, which is directly exposed to SARS-CoV-2, and communicate with various nuclei within the CNS and beyond to reach out to the PNS via the hypothalamic-pituitary-adrenocortical axis.

Therefore, the present article reviews the hypothalamic circuits and their potential involvement in neurological manifestations that are associated with viral infection, in particular, COVID-19. In addition, we considered the significant commonalities between SARS-CoV-2 and SARS-CoV infection to propose the potential mechanisms that are responsible for these neurological manifestations.

\section{CNS and Viral Infection: Transportation into the CNS}

Viral infection of the CNS represents a unique challenge that needs to be resolved efficiently by the host's immune system to avoid irretrievable damage to other crucial systems that maintain vital functions such as consciousness and balance $[9,10]$. Coronavirus $(\mathrm{CoV})$ was initially recognized as a pathogen of the respiratory tract; however, several studies have demonstrated the presence of SARS coronavirus in brain tissue specimens obtained from patients with SARS-CoV who experienced significant CNS symptoms [11]. Neuroinvasion by $\mathrm{CoVs}$ has been documented for almost all the $\beta-\mathrm{CoVs}$, including SARS$\mathrm{CoV}$, MERS-CoV, and SARS-CoV-2, and led to the development of a similar range of symptoms including headache, disturbed consciousness, hyposmia, and paresthesia $[8,12]$. Neurological manifestations of the viral infection depend mainly on the region and the cells of the brain that have been affected. Therefore, infections of the motor or sensory systems lead to abnormalities and distinct physical symptoms compared with limbic infections [13]. In addition, it was found that dopaminergic neurons were more susceptible to SARS-CoV-2 infection compared with cortical neurons or microglia [14].

Experimental evidence for neurotropism and CNS neuroinvasion of CoV was demonstrated using a large panel of human brain autopsy samples, and pathological findings of COVID-19 have revealed brain tissue edema and neuronal degeneration $[15,16]$. Other studies have shown that intranasal inoculation with $\mathrm{CoV}$ in transgenic mice that express the SARS-CoV receptor, angiotensin-converting enzyme 2 (ACE2), in the airways and other epithelia, caused infection in the airways and brain [17]. It is well documented that viral infections enter via different pathways into the CNS, and potential routes have been proposed including the blood brain barrier (BBB), cerebrospinal fluid barrier (CSF), and retrograde transport in neuronal axons. Some doubts have been raised about the involvement of the CSF as a major transportation route for SARS-CoV-2, given that clinical studies failed to detect significant levels of viral RNA in CSF [18].

The BBB and blood CSF barrier (BCSFB) are highly complex networks protecting the CNS parenchyma from toxic materials including viruses. However, they are considered to be the major routes for viral entry into the CNS [19]. Some viruses have adapted to overcome this obstacle by infecting vascular endothelial cells and creating a direct passage across these barriers to enter the CNS [20-22]. Additionally, some areas of the CNS such as the choroid plexus and the circumventricular organs including the hypothalamus are not completely protected by the BBB and can serve as virus entry points [23,24]. The use of infected hematopoietic cells as "Trojan horses" is another mean by which viruses can enter the CNS via the blood supply $[25,26]$. Inflammation-induced breakdown of the BBB and BCSFB due to systemic viral infection also allows viruses to slip through the fenestrations into the CNS [27]. 
As a second major route of CNS entry, viruses can be transported into the CNS using retrograde axonal transport in peripheral sensory nerves or via dendrites of olfactory sensory neurons that are directly exposed to inspired air in the nose [28]. Moreover, viruses that are inhaled, such as SARS-CoV-2, could quickly move past mucosal epithelial barriers and infect oropharyngeal tissues [12]. It is important to note that while viruses mainly utilize the peripheral nerve route to enter the CNS, they may utilize both routes simultaneously $[29,30]$. Viruses that remain within cells of the meninges or ventricular lining often induce meningitis, whereas those that infect the CNS parenchyma give rise to meningoencephalitis, encephalitis, or myelitis [31].

Beyrouti et al. recently reported six consecutive cases of acute ischemic stroke due to an exaggerated inflammatory immune response in COVID-19 patients, resulting in impairment of CNS function [32]. Another study has reported the development of acute necrotizing encephalitis as a result of COVID-19 infection, with lesions in areas of the brain associated with consciousness and memory function including hypothalamic circuits [33].

\section{Hypothalamic Circuits and Viral Infection}

The hypothalamus is a complex structure located at the base of the brain and composed of a large number of cell groups and neuronal circuits that are strongly interconnected [34]. Apart from complex intrahypothalamic connections, the hypothalamus projects to different regions within the brain forming large neuronal networks. The principal hypothalamic nuclei include the paraventricular nucleus (PVN), the perifornical area (PFA), the dorsomedial hypothalamus (DMH), the lateral hypothalamic area (LHA), and the caudal hypothalamus ( $\mathrm{CH}$ ) [35-37] (Figure 1). These structures are involved in the regulation of a wide range of physiological functions including respiration, integration of stress responses, thermoregulation, cardiovascular regulation, glycaemia, neuroendocrine regulation, and consciousness [37-46]. As a relay station, the hypothalamus communicates with almost all regions of the brain, in particular the brainstem, upon receiving vast peripheral sensory inputs from different sources including the olfactory system [47].

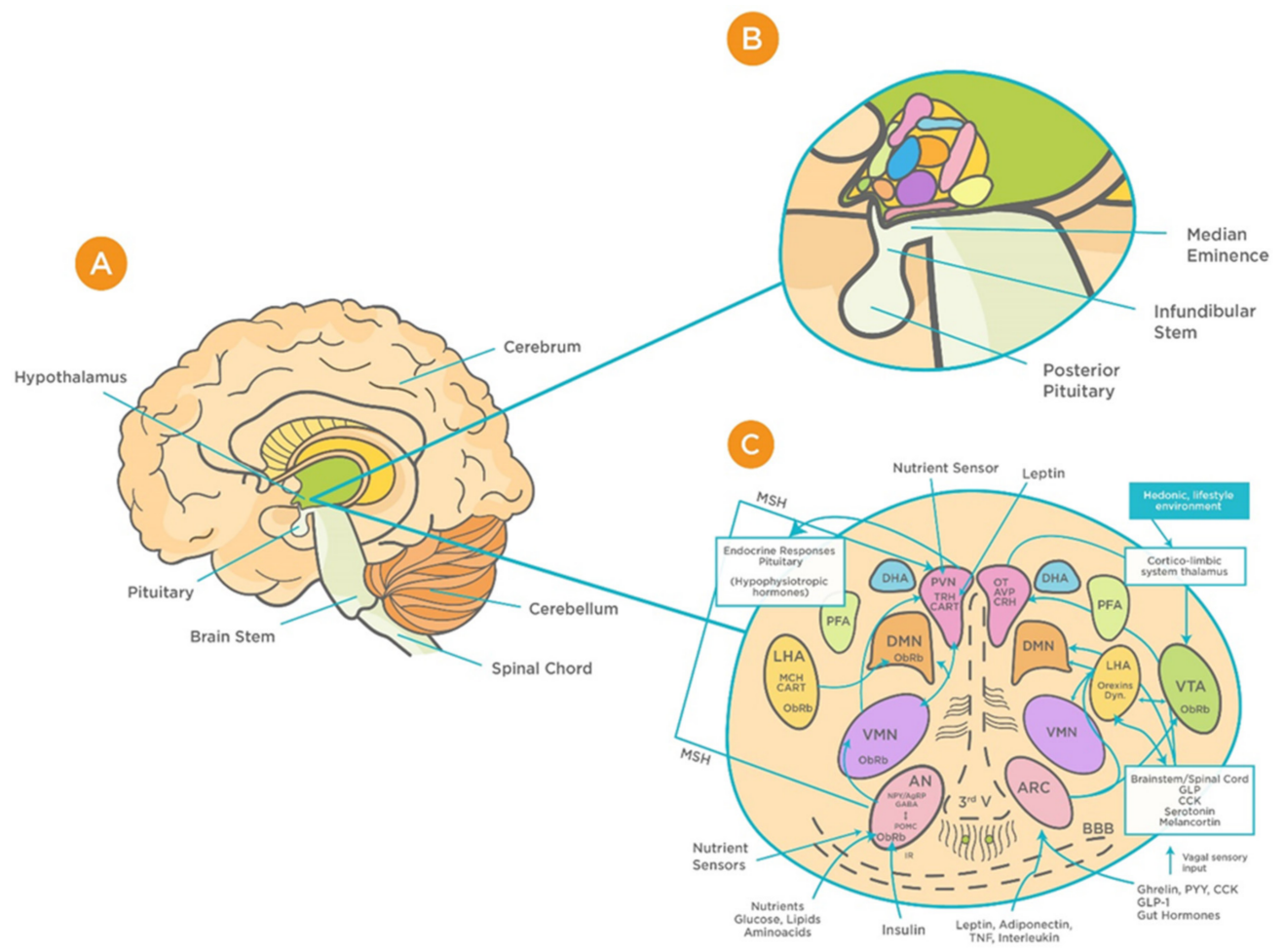

Figure 1. Schematic representation of the functional structure of hypothalamic circuits. (A) Location of hypothalamus within the ventral part of the diencephalon. (B) Location of hypothalamus in relation to the median eminence, infundibular 
stem, and pituitary glands. (C) Patterns of functional interaction between the hypothalamic nuclei (reproduced with permission from [48]). Abbreviations: AN: arcuate nucleus; AgRP: Agouti-related protein; AVP: arginine vasopressin; BBB: Blood brain barrier; CART: cocaine and amphetamine-regulated transcript; CRH: corticotrophin releasing hormone; GLP-1: Glucagon-like peptide-1; VMN: ventromedial nucleus; OT: oxytocin; DMN: dorsomedial nucleus; PVN: periventricular nucleus; DHA: dorsal hypothalamic area; IR: insulin receptor; PFA: perifornical area; LHA: lateral hypothalamic area; MCH: Melanin-concentrating hormone; MSH: melanocyte-stimulating hormones; CN: suprachiasmatic nucleus; SON: supraoptic nucleus; POA: preoptic area; POMC: Pro-opiomelanocortin; PPY: Polypeptide; ObRb: Leptin receptor; MB: mammillary bodies; ME: median eminence; NPY: Neuropeptide; III-V: third ventricle; TRH, thyrotropin-releasing hormone.

Hypothalamic BBB capillaries are fenestrated with fewer tight junctions; thus, they are highly permeable to blood-borne substances, including viruses $[49,50]$. One such region is the median eminence (ME), which is adjacent to the arcuate nucleus (AN) of the hypothalamus [50]. The unique design of barriers in the hypothalamus "allow the $\mathrm{ME}$ and AN to enjoy private milieus," with the former gaining access to the portal blood, and the latter to the CSF [50]. This makes the BBB at the ME/ARC interface play a major role in determining how hypothalamic neurons are exposed to systemic factors, including viruses [50,51]. Animal studies that have found increased viral load in the brain are suggestive of the virus's ability to exploit this leakiness and cross the BBB [51]. Such infection can result in deficiencies in essential growth and metabolism hormones. This, in turn, can cause long-term adverse effects on growth, memory, bone health, fertility, pituitary function, and hence quality of life [51-53]. Considering these consequences, it is important to address the potential effects that viral infection can have on the functioning of the hypothalamus and its associated neuroendocrine signaling as well as pituitary function-all of which are essential for normal CNS functioning. Given that these findings are observed in other viral infections, for instance the Zika virus [52], it is important to highlight the relevance of these consequences to COVID-19.

Anatomical and electrophysiological studies have shown strong neuronal connections between the olfactory system and the hypothalamus [54]. Anterograde and retrograde axonal tracing studies have revealed that projections from the olfactory system are more prominent to the lateral hypothalamus than to the thalamus [54]. Furthermore, four primary areas in the posterior lateral hypothalamus (anterior olfactory nucleus, olfactory tubercle, piriform cortex, and anterior cortical nucleus of amygdala) were shown to receive this input from the olfactory bulb [54].

Recent studies have suggested different routes for neuroinvasion of CoVs including the peripheral nervous route, hematogenous route, and through the lymphatic system [12]. However, the absence of virus particles in non-neuronal cells in the infected brain casts doubts the involvement of hematogenous or lymphatic routes, especially in the early stages of infection $[15,55,56]$. Therefore, we believe that the olfactory system may play an important role in the transportation of SARS-CoV-2 into the CNS via the hypothalamus. This hypothesis was supported by recent reports that investigated the neurological manifestations associated with SARS-CoV-2 in patients diagnosed with COVID-19 [57]. It was found that SARS-CoV-2 RNA was detected by RT-PCR in a nasopharyngeal swab specimen but not in CSF, indicating that the neuroinvasion via central routes is most likely via the olfactory system. In addition, imaging studies have shown the involvement of the hypothalamus, mammillary bodies, and dorsal midbrain [57]. This further supported the transneuronal spread of the virus, given the neuronal connection between the hypothalamus and other brain structures.

\section{Hypothalamus-Olfactory System Crosstalk}

It is believed that the olfactory bulb is the main gateway for viral entry into the brain [58]. Previous studies on transgenic mice for the SARS-CoV receptor (ACE2) have investigated the distribution of the viral antigen after intranasal inoculation and confirmed that the site of virus entry into the CNS is the olfactory bulb [58]. Recently, a mouse model expressing human ACE2 (hACE2) by using CRISPR/Cas9 knock-in technology has been 
developed, and the experiments in this model have demonstrated high viral loads in the brain upon intranasal infection, which further highlights the involvement of the olfactory system in neuroinvasion of SARS-CoV-2 [59]. Simultaneously, viral antigens were detected in other regions of the CNS that possess first- or second-order neural connections with the olfactory bulb. These include the cerebral cortex, basal ganglia, the midbrain, and the hypothalamus $[17,58]$. The suggested mechanisms for CoVs invasion include internalization in nerve terminals by endocytosis, retrograde transportation, axonal transport, and transsynaptic spread to other brain regions [60].

It has been demonstrated that the hypothalamus has complex anatomical and functional connections with the olfactory bulb. Several neuropeptides including gonadotropinreleasing hormone, neuropeptide $Y$, leptin, adiponectin, and orexins are involved in modulation of these connections [61-66] (Figure 2). In addition, studies on influenza viruses, which share several commonalities with the CoVs, have demonstrated high viral antigen expression in the olfactory bulb accompanied by cytokine induction within the bulb and hypothalamus upon intranasal infection [67]. It is noteworthy that these cytokines, which include tumor necrosis factor alpha (TNF- $\alpha$ ) and interleukin $1 \beta$ (IL-1 $\beta)$, play a critical role in triggering acute-phase responses to viral infection [68]. In agreement with previous reports, more recent evidence has demonstrated MRI alteration in the olfactory cortex of patients with COVID-19, indicating the involvement of the olfactory system in the viral neuroinvasion [69]. This became more evident using 3- and 2-dimensional fluid-attenuated inversion recovery images, which showed cortical hyperintensity in the right gyrus rectus and hyperintensity in the olfactory bulbs [69].

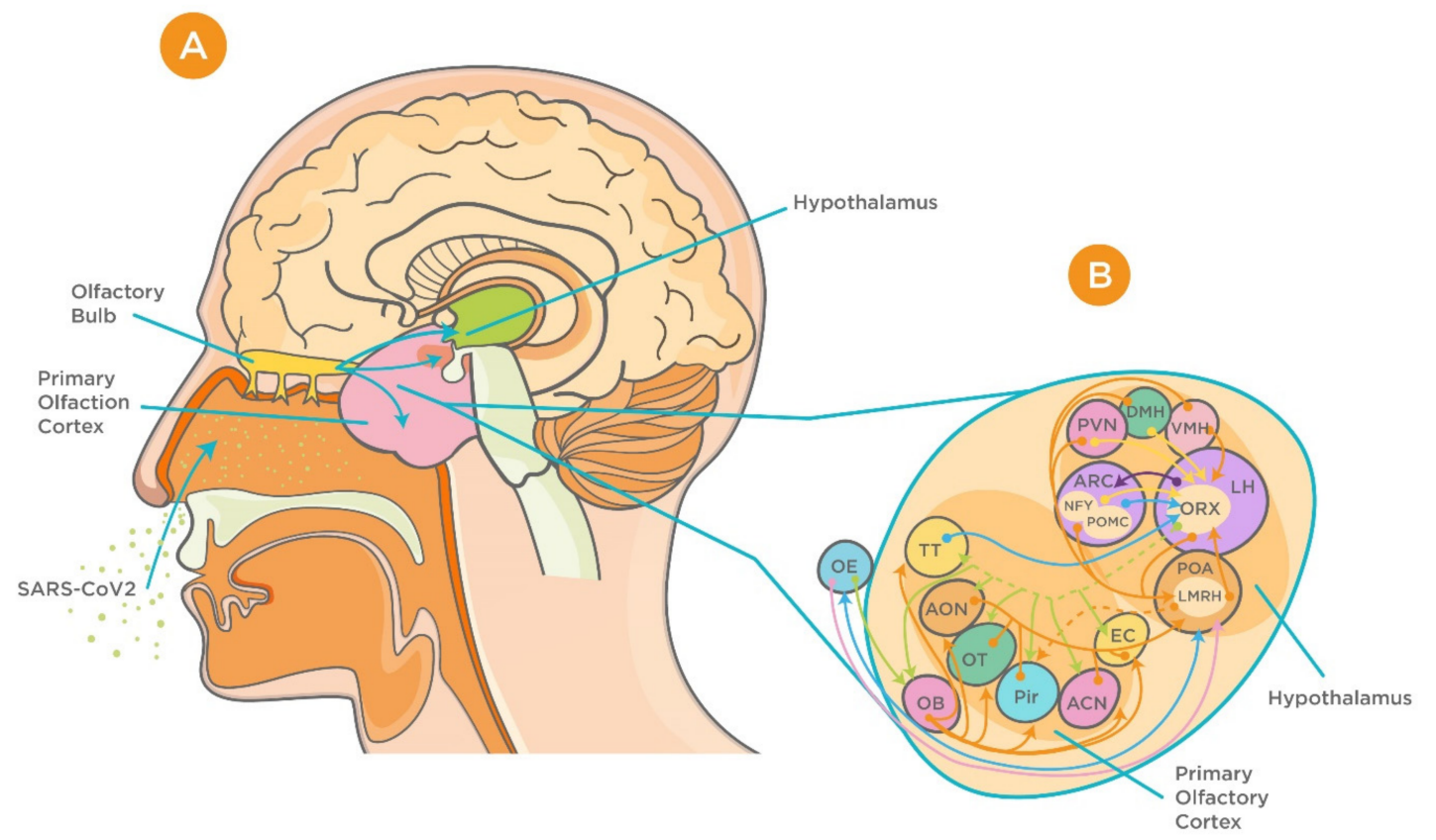

Figure 2. Proposed neuroinvasion of severe acute respiratory syndrome coronavirus 2 (SARS-CoV-2) and interrelationship between the hypothalamus and olfactory system. (A) Sagittal view of olfactory bulb, primary olfactory cortex, and the hypothalamus. (B) Complex connection between hypothalamic circuits and primary olfactory cortex (reproduced with permission from [70]). Abbreviations: ACN, amygdaloïd cortical nucleus; AON, anterior olfactory nucleus; ARC, arcuate nucleus; DMH, dorsomedial nucleus of the hypothalamus; EBOP, extra bulbar olfactory pathway; EC, entorhinal cortex; LH, lateral hypothalamus; OB, olfactory bulb; OE, olfactory epithelium; OT, olfactory tubercle; Pir, Piriform cortex; POA, preoptic area; PVN, paraventricular nucleus of the hypothalamus; TT, taenia tecta; VMH, ventromedial nucleus of the hypothalamus. 


\section{Hypothalamic Nuclei and Modulation of Respiration}

The central role of the hypothalamus in the modulation of respiration is well-documented. As early as 1962, lesion and transection experiments in cats demonstrated that inactivation/destruction of the hypothalamus led to a significant decrease in ventilation in awake cats [71]. Subsequent experiments using more sophisticated approaches, such as electrophysiology, neuropharmacology, and brain mapping, have shown that the paraventricular nucleus (PVN), perifornical area (PFA), dorsomedial hypothalamus (DMH), and lateral and posterior hypothalamus are the primary hypothalamic regions that are involved in respiratory modulation [37]. The PVN communicates with several brain regions that are considered critical for driving baseline respiration and control of breathing, including the nucleus ambiguus (NA), the nucleus of the solitary tract (NTS), the ventrolateral medulla (VLM), and the dorsal motor nucleus of the vagus [35,72-74]. In addition, the $\mathrm{PVN}$ is regarded as a prominent structure in responding to hypoxia via the activation of the chemoreflex [74-76]. Other important hypothalamic regions are the PFA and the $\mathrm{DMH}$, which also possess several neural connections with brainstem structures such as the NTS and the VLM and are prominently involved in the regulation of respiratory activities in response to stress in animals and humans $[43,77,78]$. In addition, it has been shown that both the lateral and posterior hypothalamus are involved in central regulation of coordinated respiratory activities [79]. Great emphasis has been placed on the role of the latter in modulating respiratory responses to stressful stimuli including hypoxia and hypercapnia $[80,81]$. These are considered as main features of the respiratory distress that is associated with COVID-19 [5]. Although it is well-known that the main cause of such distress is the dysfunction of the pulmonary system and not the CNS, our hypothesis is that the failure of the respiratory centers within the hypothalamus may contribute to the outcomes [82]. Further experimentation is required to confirm these suggestions.

On the other hand, recent epidemiological data regarding COVID-19 has revealed that the median time from the first symptom to dyspnea was around 5 days, and 8 and 10 days to hospital admission and intensive care, respectively [83]. Although this is certainly due to viral incubation time prior to pulmonary complications, we can also suggest that the latency period supports the view that the virus can invade and impair the function of brain regions that are involved in the regulation of respiration [60,79].

\section{ACE2 Expression in the Hypothalamus}

ACE2, a homologue of angiotensin-converting enzyme (ACE), catalyzes the conversion of angiotensin II (AII) to angiotensin-(1-7) peptide and is known to be highly expressed in the hypothalamus [84]. Within the hypothalamus, ACE2 has also been implicated in attenuating hypertension, and the balance between hypothalamic ACE2 and ACE is known to be a determinant of blood pressure [85-87]. Furthermore, ACE2 overexpression reduces local inflammation in the hypothalamus, whereas elevated AII levels induce inflammation, subsequently enhancing the mRNA levels of proinflammatory cytokines-TNF- $\alpha$, IL-1 $\beta$, and IL-6 $[87,88]$. Interestingly our recent work showed that hypothalamic miRNAs, small nucleotides that control the regulation of gene expression at the translational level, have binding sites and strong binding capacity against ACE2 and transmembrane serine protease 2 (TMPRSS2) [89].

Both subunits (S1 and S2) of the SARS-CoV are known to bind to the human receptor of ACE2, which is present on non-immune cells (endothelial cells, respiratory and intestinal epithelial cells, kidney cells, and cerebral neurons) as well as on immune cells (alveolar monocytes/macrophages) [90]. Binding of the S2 subunit to the ACE2 receptor leads to its down-regulation, which, in turn, results in excessive AII production coupled with an increase in the permeability of the pulmonary vasculature [90,91]. Amplification of the proinflammatory system due to binding of SARS-CoV-2 to ACE2 has been shown to predispose elderly persons and those with cardiovascular disease to a greater risk of COVID-19 infection and associated severity and mortality [92,93]. A similar profile is also observed in people suffering from hypertension and diabetes. These patients are usually 
given the ACE inhibitor/AT1R blocker (ACEI/ARB) treatment to increase ACE2 levels. This, however, is exploited by the SARS-CoV-2 binding to ACE2, causing further reduction in ACE2 cell surface expression, upregulating AII signaling in the lungs, and yielding acute lung injury [93]. Such hyperactivity of the ACE-AII-AT1R axis in the hypothalamus, where the ACE2 protein levels are normally low, makes it more susceptible to dysfunction. Expression of ACE2 in sustentacular cells of the nose that transfer odor from the air to sensory neurons has also been implicated in causing partial or total loss of smell, which is one of the first symptoms of COVID-19 infection [94]. This is further enhanced because of the advantage of having a leaky BBB around the hypothalamus for transportation of neuroendocrine signaling molecules within the body.

\section{Hypothalamic-Pituitary-Adrenocortical Stress Response to Viruses}

The involvement of the hypothalamus in the regulation of several hemostatic functions reaches out beyond the central environment. One of the main responses of the hypothalamus to various homeostatic challenges is the stress response, which is considered an integrated reaction to stressors such as viral infections [38]. The stress response is primarily triggered by activation of hypothalamic neurons within the PVN and release of corticotrophin releasing hormone $(\mathrm{CRH})$. CRH stimulates corticotrophs, the corticotropinproducing cells within the anterior pituitary gland, to synthesize and secrete adrenocorticotropic hormone (ACTH), which, in turn, stimulates the adrenal gland to release cortisol [95].

It is well-documented that the hypothalamic-pituitary-adrenocortical (HPA) axis plays a vital role in modulating the host's susceptibility to viral infections. It has been found that high levels of proinflammatory cytokines, particularly IL- $1 \beta$, IL-6, and TNF- $\alpha$ activate the HPA axis during the early stages of viral infections, which, in turn, stimulate the release of adrenal glucocorticoids (GCs) to suppress aggressive inflammatory attacks and regulate the immune response [96,97]. Other studies have highlighted the role of different proinflammatory cytokines such as IL-1 in the stimulation of a virus-induced stress response [98]. This represents the rationale for using GCs such as dexamethasone as a potential therapeutic agent for virus-induced respiratory diseases including COVID-19 [99,100] (Figure 3). In addition, GCs are involved in a more vital role, namely the modulation of downstream acquired immune responses, by causing a shift in immune responses from cellular (Th1/inflammatory) to humoral (Th2/anti-inflammatory) type [101]. Furthermore, GCs protect the homeostatic systems against an uncontrolled immune response by stimulating a negative feedback loop that acts directly on the pituitary gland.

It is noteworthy that SARS-CoV was identified in the adrenal glands, suggesting a direct cytopathic effect of the virus [102]. In addition, autopsies of SARS-CoV patients have shown degeneration and necrosis of the adrenal cortical cells; therefore, it was suggested that both SARS-CoV and SARS-CoV-2 may manipulate the stress response and, subsequently, cortisol dynamics [94]. This is considered as one of the main immunoinvasive strategies used by the virus to suppress the host's response [3,102]. More studies with SARS patients have provided evidence for central hypocortisolism and low dehydroepiandrosterone sulfate levels, indicating damage of the hypothalamic-pituitary circuits [103,104]. On the other hand, lymphopenia is considered as a key hematological feature of COVID19 and is strongly associated with HPA activation and GCs levels [104,105]. The latter leads to a cascade of events including induction of splenic atrophy, T cell apoptosis, and deficiency of natural killer cells which, in turn, shift hematopoietic stem cell proliferation toward the myeloid lineage resulting in lymphopenia [106,107]. 


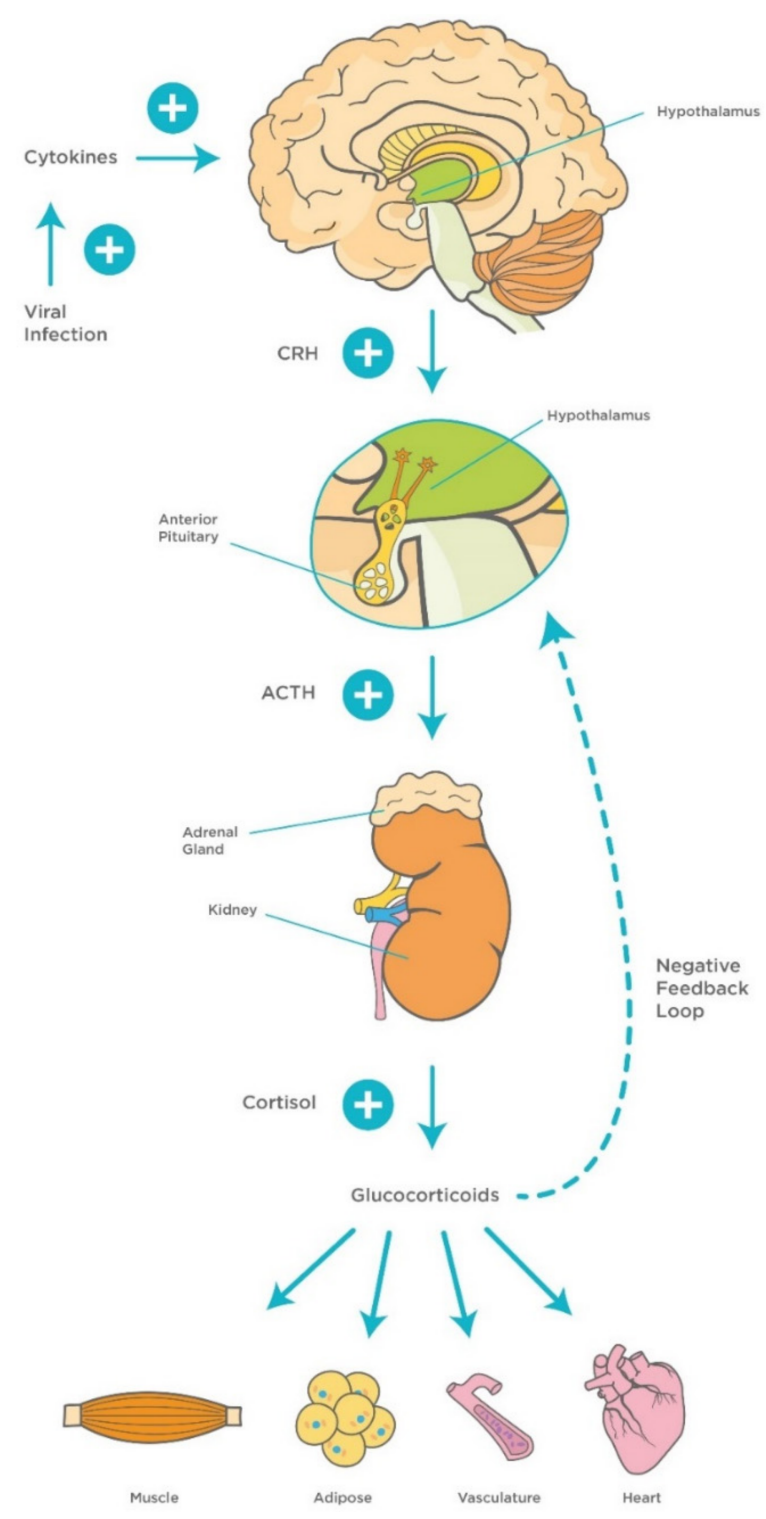

Figure 3. Mechanisms of hypothalamic-pituitary-adrenocortical (HPA) axis during viral infection. Viral infection activates innate proinflammatory cytokines (TNF- $\alpha$, IL-1, and IL-6) and interferons, and late acquired T cell cytokines (IL-2 and IFN- $\gamma$ ), which activate the HPA axis and release of GCs. This, in turn, stimulates a negative feedback loop to control the immune response. Abbreviations: $\mathrm{ACTH}$, adrenocorticotropic hormone; $\mathrm{CRH}$, corticotropin-releasing factor, TNF- $\alpha$, Tumor Necrosis Factor-alpha; IL-1, Interleukin-1; IL-6, Interleukin-6; IL-2, Interleukin-2; IFN- $\gamma$, Interferon-gamma; GCs, glucocorticoids.

\section{Future Directions}

The present review highlights the importance of the hypothalamic networks in the viral infection processes and suggests a potential role for their involvement in the development of CNS symptoms that are associated with COVID-19. Our previous work has shown that hypothalamic microRNAs play a key role in multiple functions, including food intake, energy balance, and glucose homeostasis [39]. Therefore, we believe that future studies should focus on the investigation of the role of these microRNAs in the pathogenesis of COVID-19. Recently, we have conducted in silico analyses that revealed potential hypothalamic microRNAs that can be used to identify potential therapeutic targets to treat neurological symptoms in COVID-19 patients via the regulation of ACE2 and TMPRSS2 [89]. The presence and expression of the latter may explain the selectivity of having CNS symptoms in some patients and not in others. Although the knowledge about 
the predisposing factors of neurological dysfunction associated with COVID-19 is limited, we can speculate that the following factors may play a role: preexisting medical conditions, medications, amount of viral exposure, and sub-strain of virus [108].

\section{Conclusions}

Neurological impairment that is associated with COVID-19 is most likely related to SARS-CoV-2 neuroinvasion. It is crucial to highlight that hypothalamic circuits represent an entry point for the virus via the olfactory bulb and communicate with vital respiratory networks. The hypothalamus also reaches out beyond the CNS to the periphery via the hypothalamic-pituitary-adrenocortical axis. Reviewing the aspects of the effects of COVID19 on the CNS draws attention to the importance of establishing a focused research effort to identify the exact hypothalamic circuits that may be involved in the development of neurological impairment associated with COVID-19 infection.

Author Contributions: B.M.M. developed, designed, and wrote the review; A.S. participated in the writing; A.J.M.V. edited and revised the manuscript. All authors have read and agreed to the published version of the manuscript.

Funding: This research received no external funding.

Acknowledgments: The authors would like to thank Judy Bastaty for her help in designing the figures.

Conflicts of Interest: The authors declare no conflict of interest.

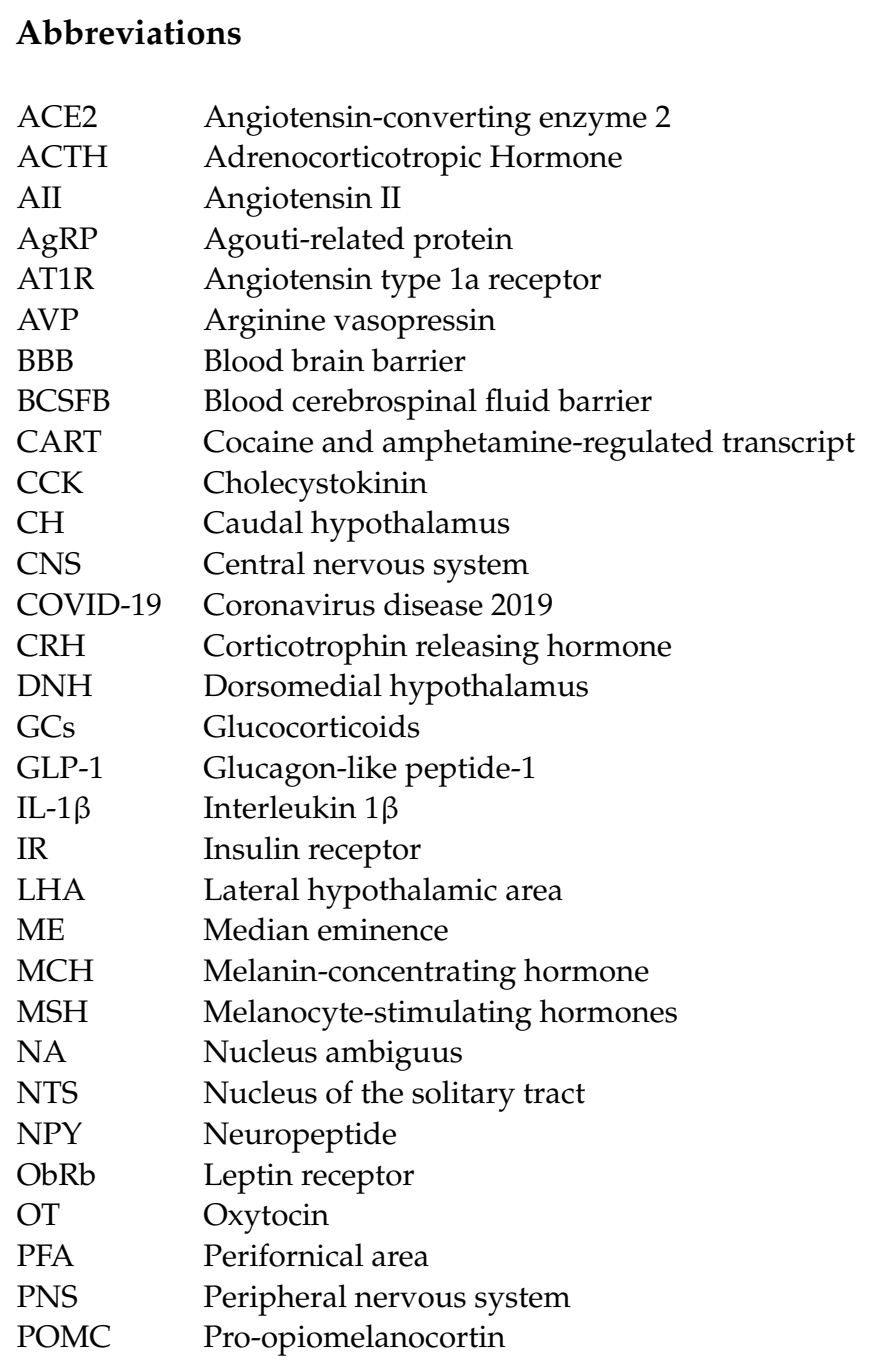




$\begin{array}{ll}\text { PVN } & \text { Paraventricular nucleus } \\ \text { PYY } & \text { Polypeptide } \\ \text { SARS-CoV-2 } & \text { Severe acute respiratory syndrome coronavirus 2 } \\ \text { TNF } \alpha & \text { Tumor necrosis factor alpha } \\ \text { TRH } & \text { Thyrotropin-releasing hormone } \\ \text { VLM } & \text { Ventrolateral medulla }\end{array}$

\section{References}

1. Du Toit, A. Outbreak of a novel coronavirus. Nat. Rev. Microbiol. 2020, 18, 123. [CrossRef]

2. World Health Organization. Coronavirus Disease (COVID-19) Pandemic Reports; World Health Organization: Geneva, Switzerland, 2020.

3. Li, X.; Geng, M.; Peng, Y.; Meng, L.; Lu, S. Molecular immune pathogenesis and diagnosis of COVID-19. J. Pharm. Anal. 2020, 10, 102-108. [CrossRef] [PubMed]

4. $\quad$ Ren, L.-L.; Wang, Y.-M.; Wu, Z.-Q.; Xiang, Z.-C.; Guo, L.; Xu, T.; Jiang, Y.-Z.; Xiong, Y.; Li, Y.-J.; Li, X.-W.; et al. Identification of a novel coronavirus causing severe pneumonia in human: A descriptive study. Chin. Med. J. 2020, 133, 1015-1024. [CrossRef] [PubMed]

5. Huang, C.; Wang, Y.; Li, X.; Ren, L.; Zhao, J.; Hu, Y.; Zhang, L.; Fan, G.; Xu, J.; Gu, X.; et al. Clinical features of patients infected with 2019 novel coronavirus in Wuhan, China [published correction appears in Lancet. Lancet 2020, 395, 497-506. [CrossRef]

6. Rothan, H.A.; Byrareddy, S.N. The epidemiology and pathogenesis of coronavirus disease (COVID-19) outbreak. J. Autoimmun. 2020, 109, 102433. [CrossRef]

7. Mao, L.; Jin, H.; Wang, M.; Hu, Y.; Chen, S.; He, Q.; Chang, J.; Hong, C.; Zhou, Y.; Wang, D.; et al. Neurologic Manifestations of Hospitalized Patients with Coronavirus Disease 2019 in Wuhan, China. JAMA Neurol. 2020, 77, 683-690. [CrossRef]

8. Wu, Y.; Xu, X.; Chen, Z.; Duan, J.; Hashimoto, K.; Yang, L.; Liu, C.; Yang, C. Nervous system involvement after infection with COVID-19 and other coronaviruses. Brain Behav. Immun. 2020, 87, 18-22. [CrossRef]

9. Chakraborty, S.; Nazmi, A.; Dutta, K.; Basu, A. Neurons under viral attack: Victims or warriors? Neurochem. Int. 2010, 56, 727-735. [CrossRef]

10. Bergmann, C.C.; Lane, T.E.; Stohlman, S.A. Coronavirus infection of the central nervous system: Host-virus stand-off. Nat. Rev. Microbiol. 2006, 4, 121-132. [CrossRef]

11. Arbour, N.; Day, R.; Newcombe, J.; Talbot, P.J. Neuroinvasion by human respiratory coronaviruses. J. Virol. 2000, 74, 8913-8921. [CrossRef] [PubMed]

12. Li, Z.; Liu, T.; Yang, N.; Han, D.; Mi, X.; Li, Y.; Liu, K.; Vuylsteke, A.; Xiang, H.; Guo, X. Neurological manifestations of patients with COVID-19: Potential routes of SARS-CoV-2 neuroinvasion from the periphery to the brain. Front Med. 2020, 14, 533-541. [CrossRef]

13. Van den Pol, A.N. Viral infection leading to brain dysfunction: More prevalent than appreciated? Neuron 2009, 64, 17-20. [CrossRef]

14. Yang, L.; Han, Y.; Nilsson-Payant, B.E.; Gupta, V.; Wang, P.; Duan, X.; Tang, X.; Zhu, J.; Zhao, Z.; Jaffré, F.; et al. A Human Pluripotent Stem Cell-based Platform to Study SARS-CoV-2 Tropism and Model Virus Infection in Human Cells and Organoids. Cell Stem Cell 2020, 27, 125-136.e7. [CrossRef]

15. Xu, J.; Zhong, S.; Liu, J.; Li, L.; Li, Y.; Wu, X.; Li, Z.; Deng, P.; Zhang, J.; Zhong, N.; et al. Detection of severe acute respiratory syndrome coronavirus in the brain: Potential role of the chemokine mig in pathogenesis. Clin. Infect. Dis. 2005, 41, 1089-1096. [CrossRef]

16. Xu, Z.; Shi, L.; Wang, Y.; Zhang, J.; Huang, L.; Zhang, C.; Liu, S.; Zhao, P.; Liu, H.; Zhu, L.; et al. Pathological findings of COVID-19 associated with acute respiratory distress syndrome. Lancet Respir. Med. 2020, 8, 420-422. [CrossRef]

17. McCray, P.B., Jr.; Pewe, L.; Wohlford-Lenane, C.; Hickey, M.; Manzel, L.; Shi, L.; Netland, J.; Jia, H.P.; Halabi, C.; Sigmund, C.D.; et al. Lethal infection of K18-hACE2 mice infected with severe acute respiratory syndrome coronavirus. J. Virol. 2007, 81, 813-821. [CrossRef]

18. Solomon, I.H.; Normandin, E.; Bhattacharyya, S.; Mukerji, S.S.; Keller, K.; Ali, A.S.; Adams, G.; Hornick, J.L.; Padera, R.F., Jr.; Sabeti, P. Neuro-pathological Features of Covid-19. N. Engl. J. Med. 2020, 383, 989-992. [CrossRef] [PubMed]

19. Ransohoff, R.M.; Kivisäkk, P.; Kidd, G. Three or more routes for leukocyte migration into the central nervous system. Nat. Rev. Immunol. 2003, 3, 569-581. [CrossRef] [PubMed]

20. Verma, S.; Lo, Y.; Chapagain, M.; Lum, S.; Kumar, M.; Gurjav, U.; Luo, H.; Nakatsuka, A.; Nerurkar, V. West Nile virus infection modulates human brain microvascular endothelial cells tight junction proteins and cell adhesion molecules: Transmigration across the in vitro blood-brain barrier. Virology 2009, 385, 425-433. [CrossRef]

21. Moses, A.V.; Bloom, F.E.; Pauza, C.D.; Nelson, J.A. Human immunodeficiency virus infection of human brain capillary endothelial cells occurs via a CD4/galactosylceramide-independent mechanism. Proc. Natl. Acad. Sci. USA 1993, 90, 10474-10478. [CrossRef] [PubMed]

22. Coyne, C.B.; Kim, K.S.; Bergelson, J.M. Poliovirus entry into human brain microvascular cells requires receptor-induced activation of SHP-2. EMBO J. 2007, 26, 4016-4028. [CrossRef] 
23. Van Den Pol, A.N.; Mocarski, E.; Saederup, N.; Vieira, J.; Meier, T.J. Cytomegalovirus cell tropism, replication, and gene transfer in brain. J. Neurosci. 1999, 19, 10948-10965. [CrossRef] [PubMed]

24. Wolinsky, J.S.; Baringer, J.R.; Margolis, G.; Kilham, L. Ultrastructure of mumps virus replication in newborn hamster central nervous system. Lab. Investig. 1974, 31, 403-412. [PubMed]

25. Clay, C.C.; Rodrigues, D.S.; Ho, Y.S.; Fallert, B.A.; Janatpour, K.; Reinhart, T.A.; Esser, U. Neuroinvasion of fluorescein-positive monocytes in acute simian immunodeficiency virus infection. J. Virol. 2007, 81, 12040-12048. [CrossRef]

26. Tabor-Godwin, J.M.; Ruller, C.M.; Bagalso, N.; An, N.; Pagarigan, R.R.; Harkins, S.; Gilbert, P.E.; Kiosses, W.B.; Gude, N.A.; Cornell, C.T.; et al. A novel population of myeloid cells responding to coxsackievirus infection assists in the dissemination of virus within the neonatal CNS. J. Neurosci. 2010, 30, 8676-8691. [CrossRef]

27. Arsenio-Nunes, M.L.; Cerutti, I.; Farkas-Bargeton, E. Vascular and neuroglial changes in experimental herpes simplex encephalitis: Ultrastructural study. Acta Neuropathol. 1975, 33, 245-256. [CrossRef]

28. Mori, I.; Nishiyama, Y.; Yokochi, T.; Kimura, Y. Olfactory transmission of neurotropic viruses. J. Neurovirol. 2005, 11, 129-137. [CrossRef]

29. Cho, H.; Diamond, M.S. Immune responses to West Nile virus infection in the central nervous system. Viruses 2012, 4, 3812-3830. [CrossRef]

30. Nathanson, N. The pathogenesis of poliomyelitis: What we don't know. Adv. Virus Res. 2008, 71, 1-50. [CrossRef]

31. Swanson, P.A., II; McGavern, D.B. Viral diseases of the central nervous system. Curr. Opin. Virol. 2015, 11, 44-54. [CrossRef]

32. Beyrouti, R.; E Adams, M.; Benjamin, L.; Cohen, H.; Farmer, S.F.; Goh, Y.Y.; Humphries, F.; Jäger, H.R.; A Losseff, N.; Perry, R.J.; et al. Characteristics of ischaemic stroke associated with COVID-19. J. Neurol. Neurosurg. Psychiatry 2020. [CrossRef]

33. Poyiadji, N.; Shahin, G.; Noujaim, D.; Stone, M.; Patel, S.; Griffith, B. COVID-19-associated Acute Hemorrhagic Necrotizing Encephalopathy: CT and MRI Features. Radiology 2020, 201187. [CrossRef] [PubMed]

34. Jenkins, J.S. The hypothalamus. Br. Med. J. 1972, 2, 99-102. [CrossRef]

35. Geerling, J.C.; Shin, J.W.; Chimenti, P.C.; Loewy, A.D. Paraventricular hypothalamic nucleus: Axonal projections to the brainstem. J. Comp. Neurol. 2010, 518, 1460-1499. [CrossRef]

36. Thompson, R.H.; Canteras, N.S.; Swanson, L.W. Organization of projections from the dorsomedial nucleus of the hypothalamus: A PHA-L study in the rat. J. Comp. Neurol. 1996, 376, 143-173. [CrossRef]

37. Fukushi, I.; Yokota, S.; Okada, Y. The role of the hypothalamus in modulation of respiration. Respir. Physiol. Neurobiol. 2019, 265, 172-179. [CrossRef]

38. Herman, J.P.; McKlveen, J.M.; Ghosal, S.; Kopp, B.; Wulsin, A.; Makinson, R.; Scheimann, J.; Myers, B. Regulation of the Hypothalamic-Pituitary-Adrenocortical Stress Response. Compr. Physiol. 2016, 6, 603-621. [CrossRef] [PubMed]

39. Mussa, B.M.; Taneera, J.; Mohammed, A.K.; Srivastava, A.; Mukhopadhyay, D.; Sulaiman, N. Potential role of hypothalamic microRNAs in regulation of FOS and FTO expression in response to hypoglycemia. J. Physiol. Sci. 2019, 69, 981-991. [CrossRef]

40. Maguire, J.; Salpekar, J.A. Stress, seizures, and hypothalamic-pituitary-adrenal axis targets for the treatment of epilepsy. Epilepsy Behav. 2013, 26, 352-362. [CrossRef]

41. Karnani, M.; Burdakov, D. Multiple hypothalamic circuits sense and regulate glucose levels. Am. J. Physiol. Integr. Comp. Physiol. 2011, 300, R47-R55. [CrossRef]

42. Nakamura, K. Central circuitries for body temperature regulation and fever. Am. J. Physiol. Integr. Comp. Physiol. 2011, 301, R1207-R1228. [CrossRef] [PubMed]

43. Dampney, R.A. Central mechanisms regulating coordinated cardiovascular and respiratory function during stress and arousal. Am. J. Physiol. Integr. Comp. Physiol. 2015, 309, R429-R443. [CrossRef]

44. Verberne, A.J.; Korim, W.S.; Sabetghadam, A.; Llewellyn-Smith, I.J. Adrenaline: Insights into its metabolic roles in hypoglycaemia and diabetes. Br. J. Pharmacol. 2016, 173, 1425-1437. [CrossRef]

45. Burbridge, S.; Stewart, I.; Placzek, M. Development of the Neuroendocrine Hypothalamus. Compr. Physiol. 2016, 6, 623-643. [CrossRef]

46. Al Zoubi, Y.; Mussa, B.M.; Srivastava, A.; Mohammed, A.K.; Abdelgadir, E.; Bashier, A.; Awadi, F.A.; Abusnana, S. Differential Expression of Inflammatory Markers in Hypoglycemia Unawareness Associated with Type 1 Diabetes: A Case Report. Brain Sci. 2020, 11, 17. [CrossRef]

47. Papp, R.S.; Palkovits, M. Brainstem projections of neurons located in various subdivisions of the dorsolateral hypothalamic area-an anterograde tract-tracing study. Front. Neuroanat. 2014, 8, 34. [CrossRef]

48. Nillni, E.A. Neuropeptides Controlling Our Behavior. In Textbook of Energy Balance, Neuropeptide Hormones, and Neuroendocrine Function; Nillni, E., Ed.; Springer: Cham, Switzerland, 2018.

49. Haddad-Tóvolli, R.; Dragano, N.R.V.; Ramalho, A.F.S.; Velloso, L.A. Development and Function of the Blood-Brain Barrier in the Context of Metabolic Control. Front. Neurosci. 2017, 11, 224. [CrossRef] [PubMed]

50. Rodríguez, E.M.; Blázquez, J.L.; Guerra, M. The design of barriers in the hypothalamus allows the median eminence and the arcuate nucleus to enjoy private milieus: The former opens to the portal blood and the latter to the cerebrospinal fluid. Peptides 2010, 31, 757-776. [CrossRef]

51. Langlet, F.; Levin, B.E.; Luquet, S.; Mazzone, M.; Messina, A.; Dunn-Meynell, A.A.; Balland, E.; Lacombe, A.; Mazur, D.; Carmeliet P.; et al. Tanycytic VEGF-A boosts blood-hypothalamus barrier plasticity and access of metabolic signals to the arcuate nucleus in response to fasting. Cell Metab. 2013, 17, 607-617. [CrossRef] [PubMed] 
52. Wu, Y.-H.; Cui, X.-Y.; Yang, W.; Fan, D.-Y.; Liu, D.; Wang, P.-G.; An, J. Zika Virus Infection in Hypothalamus Causes Hormone Deficiencies and Leads to Irreversible Growth Delay and Memory Impairment in Mice. Cell Rep. 2018, 25, 1537-1547. [CrossRef]

53. Beatrice, A.M.; Selvan, C.; Mukhopadhyay, S. Pituitary dysfunction in infective brain diseases. Indian J. Endocrinol. Metab. 2013, 17 (Suppl. 3), S608-S611. [CrossRef] [PubMed]

54. Price, J.L.; Slotnick, B.M.; Revial, M.F. Olfactory projections to the hypothalamus. J. Comp. Neurol. 1991, 306, 447-461. [CrossRef]

55. Ding, Y.; He, L.I.; Zhang, Q.; Huang, Z.; Che, X.; Hou, J.; Wang, H.; Shen, H.; Qiu, L.; Li, Z.; et al. Organ distribution of severe acute respiratory syndrome (SARS) associated coronavirus (SARS-CoV) in SARS patients: Implications for pathogenesis and virus transmission pathways. J. Pathol. 2004, 203, 622-630. [CrossRef] [PubMed]

56. Gu, J.; Gong, E.; Zhang, B.; Zheng, J.; Gao, Z.; Zhong, Y.; Zou, W.; Zhan, J.; Wang, S.; Xie, Z.; et al. Multiple organ infection and the pathogenesis of SARS. J. Exp. Med. 2005, 202, 415-424. [CrossRef]

57. Pascual-Goñi, E.; Fortea, J.; Martínez-Domeño, A.; Rabella, N.; Tecame, M.; Gómez-Oliva, C.; Querol, L.; Gómez-Ansón, B. COVID-19-associated ophthalmoparesis and hypothalamic involvement. Neurol. Neuroimmunol. Neuroinflamm. 2020, 7, e823. [CrossRef]

58. Netland, J.; Meyerholz, D.K.; Moore, S.; Cassell, M.; Perlman, S. Severe acute respiratory syndrome coronavirus infection causes neuronal death in the absence of encephalitis in mice transgenic for human ACE2. J. Virol. 2008, 82, 7264-7275. [CrossRef]

59. Sun, S.H.; Chen, Q.; Gu, H.J.; Yang, G.; Wang, Y.X.; Huang, X.Y.; Liu, S.S.; Zhang, N.N.; Li, X.F.; Xiong, R.; et al. A Mouse Model of SARS-CoV-2 Infection and Pathogenesis. Cell Host Microbe. 2020, 28, 124-133.e4. [CrossRef]

60. Dubé, M.; Le Coupanec, A.; Wong, A.H.M.; Rini, J.M.; Desforges, M.; Talbot, P.J. Axonal Transport Enables Neuron-to-Neuron Propagation of Human Coronavirus OC43. J. Virol. 2018, 92, e00404-18. [CrossRef]

61. Yoon, H.; Enquist, L.W.; Dulac, C. Olfactory inputs to hypothalamic neurons controlling reproduction and fertility. Cell 2005, 123, 669-682. [CrossRef]

62. Boehm, U.; Zou, Z.; Buck, L.B. Feedback loops link odor and pheromone signaling with reproduction. Cell 2005, 123, 683-695. [CrossRef] [PubMed]

63. Yoshida, K.; McCormack, S.; España, R.A.; Crocker, A.; Scammell, T.E. Afferents to the orexin neurons of the rat brain. J. Comp. Neurol. 2006, 494, 845-861. [CrossRef]

64. Sakurai, T.; Nagata, R.; Yamanaka, A.; Kawamura, H.; Tsujino, N.; Muraki, Y.; Kageyama, H.; Kunita, S.; Takahashi, S.; Goto, K.; et al. Input of orexin/hypocretin neurons revealed by a genetically encoded tracer in mice. Neuron 2005, 46, 297-308. [CrossRef]

65. Peyron, C.; Tighe, D.K.; Pol, A.N.V.D.; De Lecea, L.; Heller, H.C.; Sutcliffe, J.G.; Kilduff, T.S. Neurons containing hypocretin (orexin) project to multiple neuronal systems. J. Neurosci. 1998, 18, 9996-10015. [CrossRef] [PubMed]

66. Elias, C.F.; Saper, C.B.; Maratos-Flier, E.; Tritos, N.A.; Lee, C.; Kelly, J.; Tatro, J.B.; Hoffman, G.E.; Ollmann, M.M.; Barsh, G.S.; et al. Chemically defined projections linking the mediobasal hypothalamus and the lateral hypothalamic area. J. Comp. Neurol. 1998, 402, 442-459. [CrossRef]

67. Majde, J.A.; Bohnet, S.G.; Ellis, G.A.; Churchill, L.; Leyva-Grado, V.; Wu, M.; Szentirmai, É.; Rehman, A.; Krueger, J.M. Detection of mouse-adapted human influenza virus in the olfactory bulbs of mice within hours after intranasal infection. J. Neurovirol. 2007, 13, 399-409. [CrossRef] [PubMed]

68. Leyva-Grado, V.H.; Churchill, L.; Harding, J.; Krueger, J.M. The olfactory nerve has a role in the body temperature and brain cytokine responses to influenza virus. Brain Behav. Immun. 2010, 24, 281-288. [CrossRef] [PubMed]

69. Politi, L.S.; Salsano, E.; Grimaldi, M. Magnetic Resonance Imaging Alteration of the Brain in a Patient with Coronavirus Disease 2019 (COVID-19) and Anosmia. JAMA Neurol. 2020, 77, 1028-1029. [CrossRef] [PubMed]

70. Gascuel, J.; Lemoine, A.; Rigault, C.; Datiche, F.; Benani, A.; Penicaud, L.; López-Mascaraque, L. Hypothalamus-olfactory system crosstalk: Orexin a immunostaining in mice. Front. Neuroanat. 2012, 6, 44. [CrossRef]

71. Fink, B.R.; Katz, R.; Reinhold, H.; Schoolman, A. Suprapontine mechanisms in regulation of respiration. Am. J. Physiol. 1962, 202, 217-220. [CrossRef]

72. Zheng, J.Q.; Seki, M.; Hayakawa, T.; Ito, H.; Zyo, K. Descending projections from the paraventricular hypothalamic nucleus to the spinal cord: Anterograde tracing study in the rat. Okajimas Folia Anat. Jpn. 1995, 72, 119-135. [CrossRef]

73. Yeh, E.R.; Erokwu, B.; LaManna, J.C.; Haxhiu, M.A. The paraventricular nucleus of the hypothalamus influences respiratory timing and activity in the rat. Neurosci. Lett. 1997, 232, 63-66. [CrossRef]

74. Schlenker, E.; Barnes, L.; Hansen, S.; Martin, D. Cardiorespiratory and metabolic responses to injection of bicuculline into the hypothalamic paraventricular nucleus (PVN) of conscious rats. Brain Res. 2001, 895, 33-40. [CrossRef]

75. Miller, M.J.; Tenney, S.M. Hypoxia-induced tachypnea in carotid-deafferented cats. Respir. Physiol. 1975, 23, 31-39. [CrossRef]

76. Reddy, M.K.; Patel, K.P.; Schultz, H.D. Differential role of the paraventricular nucleus of the hypothalamus in modulating the sympathoexcitatory component of peripheral and central chemoreflexes. Am. J. Physiol. Regul. Integr. Comp. Physiol. 2005, 289, R789-R797. [CrossRef]

77. Suess, W.M.; Alexander, A.B.; Smith, D.D.; Sweeney, H.W.; Marion, R.J. The effects of psychological stress on respiration: A preliminary study of anxiety and hyperventilation. Psychophysiology 1980, 17, 535-540. [CrossRef] [PubMed]

78. Kabir, M.M.; Beig, M.I.; Baumert, M.; Trombini, M.; Mastorci, F.; Sgoifo, A.; Walker, F.R.; Day, T.A.; Nalivaiko, E. Respiratory pattern in awake rats: Effects of motor activity and of alerting stimuli. Physiol. Behav. 2010, 101, 22-31. [CrossRef] [PubMed] 
79. Li, N.; Li, A.; Nattie, E. Focal microdialysis of $\mathrm{CO}_{2}$ in the perifornical-hypothalamic area increases ventilation during wakefulness but not NREM sleep. Respir. Physiol. Neurobiol. 2013, 185, 349-355. [CrossRef] [PubMed]

80. Horn, E.M.; Waldrop, T.G. Modulation of the respiratory responses to hypoxia and hypercapnia by synaptic input onto caudal hypothalamic neurons. Brain Res. 1994, 664, 25-33. [CrossRef]

81. Horn, E.M.; Kramer, J.M.; Waldrop, T.G. Development of hypoxia-induced Fos expression in rat caudal hypothalamic neurons. Neuroscience 2000, 99, 711-720. [CrossRef]

82. Li, Y.C.; Bai, W.Z.; Hashikawa, T. The neuroinvasive potential of SARS-CoV2 may play a role in the respiratory failure of COVID-19 patients. J Med Virol. 2020, 92, 552-555. [CrossRef]

83. Wang, D.; Hu, B.; Hu, C.; Zhu, F.; Liu, X.; Zhang, J.; Wang, B.; Xiang, H.; Cheng, Z.; Xiong, Y.; et al. Clinical Characteristics of 138 Hospitalized Patients With 2019 Novel Coronavirus-Infected Pneumonia in Wuhan, China. JAMA 2020, 323, 1061-1069. [CrossRef]

84. Santos, R.A.; Ferreira, A.J.; Verano-Braga, T.; Bader, M. Angiotensin-converting enzyme 2, angiotensin-(1-7) and Mas: New players of the renin-angiotensin system. J. Endocrinol. 2013, 216, R1-R17. [CrossRef]

85. Sriramula, S.; Xia, H.; Xu, P.; Lazartigues, E. Brain-targeted angiotensin-converting enzyme 2 overexpression attenuates neurogenic hypertension by inhibiting cyclooxygenase-mediated inflammation. Hypertension 2015, 65, 577-586. [CrossRef]

86. Xia, H.; De Queiroz, T.M.; Sriramula, S.; Feng, Y.; Johnson, T.; Mungrue, I.N.; Lazartigues, E. Brain ACE2 overexpression reduces DOCA-salt hypertension independently of endoplasmic reticulum stress. Am. J. Physiol. Regul. Integr. Comp. Physiol 2015, 308, R370-R378. [CrossRef]

87. Wang, K.; Xu, Y.; Yang, W.; Zhang, Y. Insufficient hypothalamic angiotensin-converting enzyme 2 is associated with hypertension in SHR rats. Oncotarget 2017, 8, 20244-20251. [CrossRef]

88. Oudit, G.Y.; Kassiri, Z.; Patel, M.P.; Chappell, M.; Butany, J.; Backx, P.H.; Tsushima, R.G.; Scholey, J.W.; Khokha, R.; Penninger, J.M. Angiotensin II-mediated oxidative stress and inflammation mediate the age-dependent cardiomyopathy in ACE2 null mice. Cardiovasc. Res. 2007, 75, 29-39. [CrossRef]

89. Mukhopadhyay, D.; Mussa, B.M. Identification of Novel Hypothalamic MicroRNAs as Promising Therapeutics for SARS-CoV-2 by Regulating ACE2 and TMPRSS2 Expression: An In Silico Analysis. Brain Sci. 2020, 10, 666. [CrossRef]

90. Magrone, T.; Magrone, M.; Jirillo, E. Focus on Receptors for Coronaviruses with Special Reference to Angiotensin-converting Enzyme 2 as a Potential Drug Target-A Perspective. Endocr. Metab. Immune Disord. Drug Targets 2020, 20, 807-811. [CrossRef]

91. Kuba, K.; Imai, Y.; Rao, S.; Gao, H.; Guo, F.; Guan, B.; Huan, Y.; Yang, P.; Zhang, Y.; Deng, W.; et al. A crucial role of angiotensin converting enzyme 2 (ACE2) in SARS coronavirus-induced lung injury. Nat. Med. 2005, 11, 875-879. [CrossRef]

92. AlGhatrif, M.; Cingolani, O.; Lakatta, E.G. The Dilemma of Coronavirus Disease 2019, Aging, and Cardiovascular Disease: Insights from Cardiovascular Aging Science. JAMA Cardiol. 2020. [CrossRef]

93. Hoffmann, M.; Kleine-Weber, H.; Schroeder, S.; Krüger, N.; Herrler, T.; Erichsen, S.; Schiergens, T.S.; Herrler, G.; Wu, N.-H.; Nitsche, A.; et al. SARS-CoV-2 Cell Entry Depends on ACE2 and TMPRSS2 and Is Blocked by a Clinically Proven Protease Inhibitor. Cell 2020, 181, 271-280. [CrossRef]

94. Bilinska, K.; Jakubowska, P.; Von Bartheld, C.S.; Butowt, R. Expression of the SARS-CoV-2 Entry Proteins, ACE2 and TMPRSS2, in Cells of the Olfactory Epithelium: Identification of Cell Types and Trends with Age. ACS Chem. Neurosci. 2020, 11, 1555-1562. [CrossRef]

95. Pacak, K.; Palkovits, M.; Kopin, I.J.; Goldstein, D.S. Stress-induced norepinephrine release in the hypothalamic paraventricular nucleus and pituitary-adrenocortical and sympathoadrenal activity: In vivo microdialysis studies. Front. Neuroendocrinol. 1995, 16, 89-150. [CrossRef]

96. DeRijk, R.H.; Petrides, J.; Deuster, P.; Gold, P.W.; Sternberg, E.M. Changes in corticosteroid sensitivity of peripheral blood lymphocytes after strenuous exercise in humans. J. Clin. Endocrinol. Metab. 1996, 81, 228-235. [CrossRef]

97. Sternberg, E.M. Neuroendocrine regulation of autoimmune/inflammatory disease. J. Endocrinol. 2001, 169, 429-435. [CrossRef]

98. Besedovsky, H.O.; del Rey, A. Mechanism of virus-induced stimulation of the hypothalamus-pituitary-adrenal axis. J. Steroid Biochem. 1989, 34, 235-239. [CrossRef]

99. Halpin, D.M.G.; Singh, D.; Hadfield, R.M. Inhaled corticosteroids and COVID-19: A systematic review and clinical perspective. Eur. Respir. J. 2020, 55, 2001009. [CrossRef]

100. Russell, B.; Moss, C.; Rigg, A.; Van Hemelrijck, M. COVID-19 and treatment with NSAIDs and corticosteroids: Should we be limiting their use in the clinical setting? Ecancermedicalscience 2020, 14, 1023. [CrossRef]

101. Silverman, M.N.; Pearce, B.D.; Biron, C.A.; Miller, A.H. Immune modulation of the hypothalamic-pituitary-adrenal (HPA) axis during viral infection. Viral Immunol. 2005, 18, 41-78. [CrossRef] [PubMed]

102. Pal, R. COVID-19, hypothalamo-pituitary-adrenal axis and clinical implications. Endocrine 2020, 68, 251-252. [CrossRef]

103. Leow, M.K.; Kwek, D.S.; Ng, A.W.; Ong, K.C.; Kaw, G.J.; Lee, L.S. Hypocortisolism in survivors of severe acute respiratory syndrome (SARS). Clin. Endocrinol. 2005, 63, 197-202. [CrossRef] [PubMed]

104. Chen, G.; Wu, D.; Guo, W.; Cao, Y.; Huang, D.; Wang, H.; Wang, T.; Zhang, X.; Chen, H.; Yu, H.; et al. Clinical and immunological features of severe and moderate coronavirus disease 2019. J. Clin. Investig. 2020, 130, 2620-2629. [CrossRef]

105. Qin, C.; Zhou, L.; Hu, Z.; Zhang, S.; Yang, S.; Tao, Y.; Xie, C.; Ma, K.; Shang, K.; Wang, W.; et al. Dysregulation of Immune Response in Patients with Coronavirus 2019 (COVID-19) in Wuhan, China. Clin. Infect. Dis. 2020, 71, 762-768. [CrossRef] 
106. Iadecola, C.; Buckwalter, M.S.; Anrather, J. Immune responses to stroke: Mechanisms, modulation, and therapeutic potential. J. Clin. Investig. 2020, 130, 2777-2788. [CrossRef]

107. Shaath, H.; Vishnubalaji, R.; Elkord, E.; Alajez, N.M. Single-Cell Transcriptome Analysis Highlights a Role for Neutrophils and Inflammatory Macrophages in the Pathogenesis of Severe COVID-19. Cells 2020, 9, 2374. [CrossRef]

108. Assari, S. COVID-19 Pandemic and Neurological Disease: A Critical Review of the Existing Literature. Hosp Pract Res. 2020, 5 , 81-86. [CrossRef] 